\title{
AMANAH DALAM PERSPEKTIF HADIS
}

\author{
Reza Pahlevi Dalimunthe \\ Dosen Fakultas Ushuluddin UIN Sunan Gunung Djati Bandung \\ J1. AH. Nasution No. 105, Bandung, Indonesia \\ E-Mail: Reza32ind@yahoo.com
}

\begin{abstract}
Amanah is God's gift to the sky but the sky is not able to carry it, only humans who dared to accept the mandate it. Amanah, Hugo is a noble trait that has been attached to the Apostles themselves. The opposite of the treasonous, because treasonous is one of the signs of hypocrisy and Islam strictly forbid it. Amanah in reality is not so simple, because by their mandate means no loading or demand for the concerned to realize. Various methods were used to reveal the meaning and intent of the terms of the trust both in the hadith. From there will appear a comprehensive understanding of the mandate This article seeks to unravel the mandate and matters related to the mandate covers and Nature of Amanah, Criteria Amanah Amanah based on the Hadith. Not only as an perspectife religion but also the effort to achieve skill academic development.
\end{abstract}

Keywords: Ahli; Amanah; Fuction; Hadis; Heaven.

\begin{abstract}
Abstrak
Amanah merupakan anugerah Allah kepada langit tapi langit tidak mampu mengembannya, hanya manusia yang berani menerima amanah itu. Amanah, huga merupakan sifat mulia yang telah melekat pada diri Rasul. Sebaliknya yaitu khianat, karena khianat adalah salah satu tanda-tanda kemunafikan dan islam sangat melarang hal itu. Amanah pada kenyataannya tidak semudah yang dipikirkan karena dengan adanya amanah berarti ada pembebanan atau tuntutan bagi yang bersangkutan untuk merealisasikan. Berbagai metode digunakan dalam mengungkap makna dan maksud dari term-term amanah baik dalam hadis . Dari situlah akan muncul sebuah pemahaman yang komprehensif tentang amanah

Artikel ini berusaha mengungkapkan makna amanah dan hal-hal yang terkait dengan amanah meliputi dan Hakikat Amanah, Kriteria Amanah, Ganharan Amanah berbasis kepada hadis nabi. Bukan hanya sebagai wawasan keagamaantetapi huga sebagai bentuk pengembangan kahian akademis.
\end{abstract}

Kata Kunci: Hadis; Muhadisun, Sahabat; Keadilan; Ahli Sunnah.

\section{A. PENDAhULUAN}

Sebuah kutipan ceramah Almarhum Zainuddin MZ memberi pesan kepada kita bahwa kalau sesuatu diserahkan kepada yang bukan ahlinya maka tunggu kehancuran. Pernyataan ini mengutip dari

$$
\begin{aligned}
& \text { عن أبي هريرة رضي الله عنه قال : قال رسول الله } \\
& \text { صلى الله عليه و سلم إذا ضيعت الأمانة فانتظر } \\
& \text { الساعة .قال كيف إضاعتها يا رسول الله ؟ قال إذا } \\
& \text { أسند الأمر إلى غير أهله فانتظر الساعة } 1 .
\end{aligned}
$$

1 Muhammad bin Isma'il Abu Abdullah AlBukhori, Al-Jami' Al-Shohih Al-Bukhori AlMukhtasar, ed. by Musthafa Dib (Beirut: Darr Ibnu Katsir, 1987). no. Hadits (6131) bab "Al-Amanah", 5/2382. Lihat juga pada bab "Man Suila 'Ilman Wa Huwa Musytaghilun Fi Hadisihi” no hadits (59)
Artinya: Rasulullah saw., bersabda: apabila amanah telah dicabut maka tunggulah kehancuran (kiamat), Abu Hurairah bertanya bagaimana dicabutnya amanah ya Rasulullah? Nabi menhawab: apabila sesuatu telah diserahkan kepada yang bukan ahlinya maka tunggulah kehancuran.

Umar bin abdul aziz ketika diangkat menhadi amirul mukminin, beliau langsung pesta menangis malamnya di mihrab meshid. Istrinya Fatimah menanyakan kenapa dia menangis, umar menhawab kalau dia membayangkan rasa takut yang mendalam kalau-kalau dia menzdalimi rakyatnya. Begitu diangkat istrinya mendapat kiriman hadiah yang banyak berupa sutra, berlian, intan, dan barang-barang berharga lainnya. Umar bertanya : apakah istrinya senang mendapatkan hadiah tersebut ? senang sahut 
istrinya. Umar : kalau kau senang maka kau boleh pakai semua itu tapi besok kita cerai. Umar : kalau kau cinta sama saya maka hual semua pemberian itu dan berikan ke baitul mal.

Suatu malam umar bin abdul aziz sedang bekerha di kantornya memakai lampu petromak. Kemudian dia kedatangan tamu dengan tuhuan urusan pribadi. Maka umar mematikan lampu petromak itu karena minyaknya adalah atas dana negara. ${ }^{2}$

Wacana ini memang terus berkembang, dan untuk itu perlu kahian ulang terhadap bagaimana sebenarnya konsep amanah dalam Islam. Namun makalah ini hanya akan membahas : Bagaimana hakikat amanah menurut perspektif hadis serta wilayah amanah yang dikandung oleh hadis ?

\section{B. PEMBAHASAN}

Hadis-hadis tentang amanah dan permasalahannya pada makalah ini akan dipaparkan langsung pada sub-sub tema yang akan dibahas pada bagian berikutnya. Namun secara umum setelah memperhatikan ekasistensi hadis-hadis amanah pada buku-buku al-mashodir al-ashliah baik dengan mencari hadis yang mengandung term "الأمانة" atau term yang senada substansinya, maka sub-sub tema itu adalah sebagai berikut: Pengertian dan Hakikat Amanah, Kriteria Amanah, Ganharan Amanah.

\section{Pengertian}

Kata "amanah" berasal dari "al-hamzah", "mim", "nun", kata ini mengarah pada dua pokok makna kata yang berdekatan : 1. Al-amanah lawan kata dari al-khiyanah yaitu suk-n al-qalb (ketenangan hati). 2. Al-tasdiq : mempercayakan. Kedua arti di atas saling berdekatan. Al-Kholil mengatakan : الأمنة dari kata الأمن darti memberi rasa aman. Sementara الأمانة adalah lawan kata dari al-khianah. ${ }^{3}$

Kata أمن dan الأمن danan dan amanah. Al-amanu lawan kata dari al-khauf (takut), sementara al-amanah lawan kata al-

2 zainudin MZ, 'Menjaga Amanah Allah SWT (Damai Indonesiaku).”' (Indonesia: TV ONE, 2014).

${ }^{3}$ Abi al-Husain Ahmad Faris bin Zakaria, Mu'jam Al-Maqayis Fi Al-Lughah, ed. by Abdussalam Muhammad Harun (Beirut: Darr al-Fikr, 1979). Jilid $1,133-134$ khianah. Al-Iman lawan kata dari al-kufur. ${ }^{4}$ Yang diberi amanah disebut makmun atau amin berarti pengemban amanah, muktaminun adalah orang yang mengamanahi. ${ }^{5}$

Dalam kitab Syar¥ Hud-d dikatakan bahwa kata al-amanah adalah sinonim dari al-wad'ah yaitu menyatakan suatu pebuatan meminta tolong menggatikan menhaga sesuatu baik urusan yang menyangkut hak Allah atau hak manusia. Allah

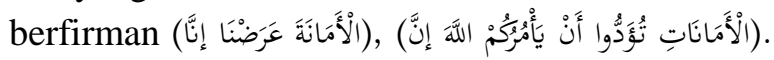
Ini artinya titipan yang menyangkut hak Allah dan Manusia harus ditunaikan secara proporsional. $^{6}$

Dalam kitab Ihya Ulumuddin amanah adalah bersihnya diri secara batin dari kefasikan, dosadosa besar, menghindari dosa-dosa kecil. ${ }^{7}$

\section{Hakikat Amanah}

\section{Hadis 1}



\footnotetext{
${ }^{4}$ Zakaria. jilid13, 21

5 Al-Khalil bin Ahmad, 'Al-'Ain' (Beirut:
} www.alwarraq.com, al-Maktabah al-Syamilah). Jilid 2, 202. Lihat juga Shahib Bin 'Ubad, al-Muhi' fi alLughah, (www.alwarraq.com, al-Maktabah alSyamilah), jilid 2, 476 .

6 Ibnu 'Arafah, 'Syarh Hudud Ibnu 'Arafah' (www.al-islam.com, al-Maktabah al-Syamilah). 2/193

7 Abu Hamid Muhammad bin Muhammad bin Muhammad al-Ghazaliy Al-siy, 'Ihya Ulumuddin' (alMaktabah al-Syamilah). ditakhrij oleh al-Hafizh al'Iraqiy, jilid1, 339. 


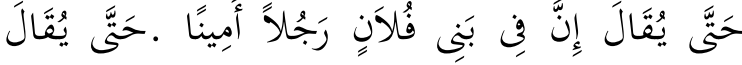

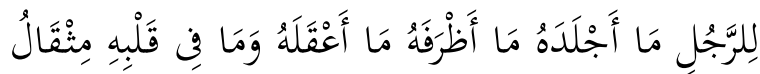

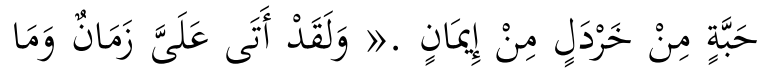

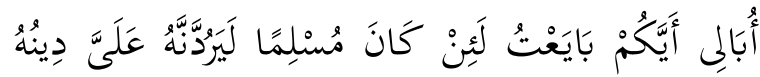

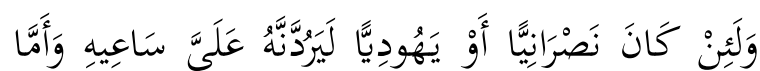

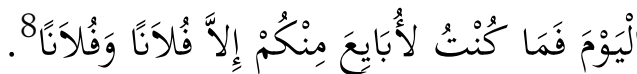

Artinya : (Bahwa amanah turun dari langit pada lubuk hati manusia yang paling dalam, dan setelah al-Qur'an turun maka mereka membaca al-Qur'an baru mereka mengetahui sunnah). Kemudian kami meriwayatkan tentang "diangkatnya amanah": (seseorang sedang tertidur maka diambil amanah dari hatinya maka tinggallah bekasnya seperti plak, kemudian dia tidur lalu diambil lagi amanah dari hatinya maka tinggal bekasnya seperti herawat seperti bara api yang hatuh ke kakimu maka melepuh dan bengkak padahal didalamnya, kemudian dia ambil batu dan dia hatuhkan ke kakinya, maka orang itu mengucapkan sumpah (menyumpahi) hampir tidak ada orang yang memegang amanah hingga dikatakan : sesungguhnya di kalangan itu ada orang yang amanah. Hingga dikatakan pada orang itu aku tidak merasakan, aku tidak memikirkan dan tidak mengingatnya dan tidak ada di hatinya sebihi krikil keimanan.)

Kritik Sanad

$$
\begin{aligned}
& \text { أَبُو بَكْرِ بْنُ أَبِى شَيْبَة : ثققة .أَبْو مُعَاوِيََة) شَيْبَانُ بنُ }
\end{aligned}
$$

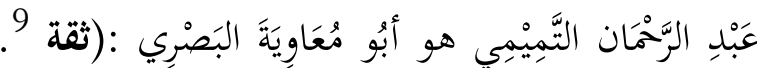

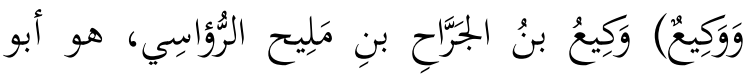

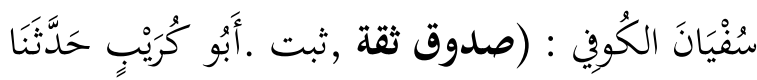

$$
\begin{aligned}
& \text { أَبُوُ مُعَاوِيَة عَنِ الأَعْمَشِِ عَنْ زَيْدِ بْنِ وَهْبِ }
\end{aligned}
$$

\section{Kritik matan}

Matan hadis ini didukung oleh beberapa riwayat dengan teks matan yang sama, sehingga tidak ada syadz . untuk mendukung pernyataan ini maka bisa dibuktikan dengan

\footnotetext{
${ }^{8}$ Abu al-Husain Muslim bin al-Hajjaj bin Muslim al-Qusyairiy Al-Naisaburiy, Shahih Muslim (Beirut: Darr al-Jail).Abu al-Husain Muslim bin al-Hajjaj bin Muslim al-Qusyairiy al-Naisaburiy, Shahih Muslim, (Beirut:Darr al-Jail, t.t), no hadits (388), 1/88

${ }^{9}$ Jamaluddin abi al-Hajjaj Yusuf al-Miziy, Tahzib Al-Kamal. no Rawiy (1325), jilid 4, 267.
}

data data hadis lain. Hadis ini huga diriwayatkan oleh Muslim (323) 2/137, Ahmad dalam Musnadnya (22871) 6/529, Ibnu Hibban dalam shohihnya (6648) 6/209.s Hadis 2

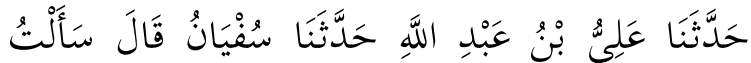



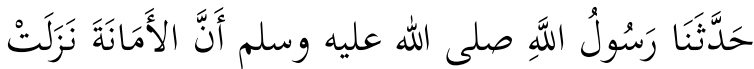

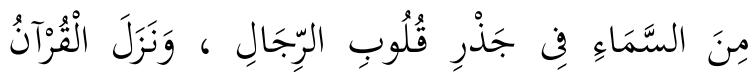

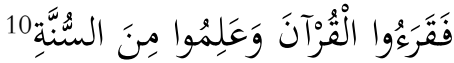

Artinya : Bahwa amanah turun dari langit pada lubuk hati manusia yang paling dalam, dan setelah alQur'an turun maka mereka membaca al-Qur'an baru mereka mengetahui sunnah.

\section{Kritik Sanad}

$$
\begin{aligned}
& \text { عَلِليُّ بْنُ عَبْدِ اللَّهِ : ثقة ثبت إمام ,سُفْيَانُ) هو ابن } \\
& \text { عيينة:(ثقة حافظ فقيه إمام حجة , الأَعْمَشَ) هو }
\end{aligned}
$$

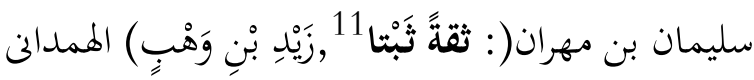

$$
\begin{aligned}
& \text { الجهني الكوفي:(ثقة) }
\end{aligned}
$$

Lataif al-Isnad (Keindahan Sanad)

1. Isnad hadis memiliki periwayatperiwayat yang semuanya adalah orang Kufah. Huzaifah sendiri aslinya adalah orang madinah tetapi sudah menetap di Kufah. Ada Pernyataan bahwa al-A'masy pernah melakukan tadlis, dan seorang mudallis riwayatnya ditolak hika ia meriwayatkan dengan shighah " an". Hawaban terhadap permasalahan ini bahwa pada hadis terbukti al-A'masy mendengar langsung dari Zaid bin Wahab. Dengan demikian tidak ada permasalahan dengan penggunaan "an" disini. ${ }^{13}$ Dan tadlis yang ada

\footnotetext{
${ }^{10}$ Al-Bukhori. no Hadits (6132, 6848), 6/2655

11 Ibnu Hajar Al-'Asqalaniy, Tahzib Tahzib. no rawy (386), 4/196

12 Jamaluddin abi al-Hajjaj Yusuf al-Miziy. no Rawiy (2131), jilid 10, 113.

13 Imam Al-Nawawiy, Syarh Al-Nawawiy 'Ala Shohih Muslim (Beirut: Darr Al-Fikr, 1995). (Program CD Al-Marja al-Akbar li al-Turats al-Islamiy) Kitab
} 
penhelasannya bisa diterima dengan catatan terbukti tsiqah dari tsiqah.

2. Shighah al-Tahdits dalam hadis ini semua memakai " kecuali al-A'masy yang memakai "عن"

Dari data yang didapatkan di atas maka bisa diambil kesimpulan bahwa hadis ini shohih. Namun dalam menelusuri biograpi para periwayat masih terdapat kesusahan dimana sanad hadis ini mencantumkan nama yang tidak lengkap. Sehingga harus dilakukan penelusuran kembali siapa sebenarnya nama periwayat yang dimaksud karena terdapat nama-nama yang sama dan atau hulukan serta nasab yang sama.

\section{Syarah Hadis}

Amanah adalah perintah atau kewahiban yang Allah bebankan kepada hambanya serta hanhi yang Allah ambil dari mereka. ${ }^{14}$

Hadis ini memberi pengertian bahwa amanah adalah permasalahan hati. Setiap orang terlahir dengan memiliki sifat amanah. Sifat amanah itu seiring perkembangan pengalaman hidup seseorang bisa menhadi lebih kuat atau malah terkikis oleh pengalaman hidupnya huga. Dari itu betul hadis nabi yang mengatakan bahwa diantara langkah untuk menhaga hati adalah banyak membaca al-qur'an dan bergaul dengan orang soleh. Ini sehalan dengan hadis di atas bahwa manusia diminta untuk memahami alQur'an dan Sunnah (matluw dan ghairu matluw).

Kemudian perumpamaan luka pada hadis di atas tentang diangkatnya amanah adalah perumpamaan dimana hati yang bersih akan terus meninggalkan luka seiring dengan pengalaman hidup yang tidak Qur'aniy. Semakin banyak maksiat yang dilakukan maka semakin banyak bintik-bintik yang tertinggal di dalam hati. Kata tidur dalam hadis menunhukkan simbol kelalaian manusia untuk terus pada halan yang lurus. Bisa huga diartikan hadis di atas bahwa betapa manusia sangat cepat lupa akan lukaluka kecil yang perah ia alami, sampai-

al-Iman, Bab “Rof”u al-Amanah wa al-Iman min Ba'di al-Qulub" 2/137

${ }^{14}$ Al-Nawawiy. Jilid 2,137. sampai seperti tidak pernah terhadi. Ini merupakan proses pencabutan amanah secara perlahan dari diri manusia.

Nawawiy menhelaskan hal yang selaras dengan hal ini bahwa hadis 1 berkaitan erat dengan degradasi iman yang terhadi pada hati seseorang dengan hal-hal ringan. ${ }^{15}$ Hadis lain yang mendukung pernyataan ini :

$$
\begin{aligned}
& \text { حدّثنا عبد الله ، ححَّثني أبي، حدثنا بهز ، حدثنا أبو } \\
& \text { هلال ، حدثنا قتادة ، عن أنس بن مالك قاله :ما } \\
& \text { خطبنا نبي الله صلى الله عليه وسلّم إلا قال :لا إيمان } \\
& \text { لمن لا أمانة له، ولا دين لمن لا عهد له } 16 .
\end{aligned}
$$

Artinya : Rasul tidak menceramahi kami kecuali berkata : tidak beriman seseorang yang tidak amanah, tidak beragama orang yang tidak memenuhi hanhi.

Kualitas hadis ini adalah Hasan menurut takhrih yang dilakukan oleh Syu'aib alArna-tiy. Sanadnya memiliki periwayatperiwayat yang tsiqah dan merupakan periwayat-periwayat pada sanad al-Syaikhon kecuali Abi Hilal dimana kebanyakan muridnya adalah shohib al-sunan. Pada kesempatan lain al-Arnauthiy mengatakan $l a$ yu'rof. ${ }^{17}$

Dalam kitab Faidh al-Bariy dihelaskan bahwa amanah adalah salah satu corak dari iman. Hadi amanah adalah bagian dari iman, sehingga tidak sempurna iman seseorang kalau tidak amanah. ${ }^{18}$ Dapat ditarik pernyataan bahwa permasalahan amanah tidak terpisahkan antara hablum minalloh dan hablum minannas.

Hadis lain yang menhelaskan bahwa amanah secara singkat dapat diidentifikasi pada diri seseorang bisa dilihat pada hadis berikut :

$$
\begin{aligned}
& \text { حدثنا عبد الله حدثني أبي حدثنا أبو سلمة الخزاعي } \\
& \text { حدثنا سليمان بن بلال عن عبد الرحمن بن عطاء أن }
\end{aligned}
$$


عبد الملك بن جابر بن عتيك أخبره أن جابر بن عبد

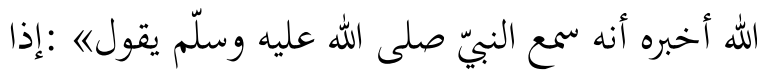

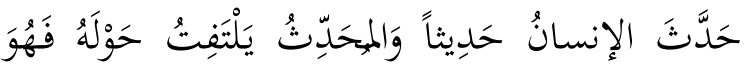
أمانَّهُ 19.

Artinya: Apabila seseorang mempresentasikan (menyempaikan) sesuatu, dan pembicara tersebut memperhatikan sekitarnya maka itu adalah amanah.

\section{Kritik Sanad dan matan:}

$$
\text { حسنيق شعيب الأرنؤوط : حسن لغيره وهذا إسناد الشواهد من أجل عبد الرحمن بن عطاء }
$$

1. Dalam kitab Tahzib Tahzib dihelaskan bahwa Abdurrahman Bin 'Atha Bin Ka'ab Al-Mad³niy adalah "syaikhun"20

2. Hadis ini diperkuat oleh tabi' hadis dengan perbedaan teks namun substansi sama.

$$
\begin{aligned}
& \text { حدثنا عبد الله حدثني أبي ثنا أبو عامر ثنا ابن أبي } \\
& \text { ذئب عن عبد الرحمن بن عطاء عن عبد الملك بن } \\
& \text { جابر بن عتيك عن جابر بن عبد الله أن النبيّ صلى }
\end{aligned}
$$

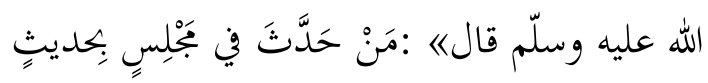

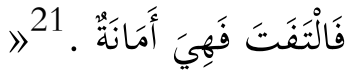

\section{Syarah Hadis}

Hadis ini mengisyaratkan bahwa pada pandangan pertama dapa huga diidentipikasi tanda-tanda bawaan aura seseorang dari tindakan dan gaya bicaranya yang mengarah kepada identifikasi amanah dalam dirinya. Artinya ketika seseorang tidak mengabaikan rambu-rambu tata cara berbicara, hingga tidak ada yang tersinggung, atau tidak ada bahasan pembicaraan yang tidak sehalan dengan larangan agama seperti ghibah, hasud, dan ghisy.

\footnotetext{
${ }^{19}$ Ahmad bin Hanbal, Musnad Ahmad Bin Hanbal, ed. by Syu'aib Al-Arnauthiy (Mu'assasah Risalah, 1999). no Hadits (14792), juz 23, 105.

${ }^{20}$ Al-'Asqalaniy. jilid 3, 441.

${ }^{21}$ Al-Syaibaniy. no Hadits (14186)
}

Dalam hal ini sebenarnya lebih cendrung pada terhaganya rahasia-rahasia atau aib-aib yang mungkin terbuka hika aturan bicara tidak diindahkan. Dalam hal ini termasuk menhaga rahasia semasa orang bersangkutan masih hidup atau sudah wafat. Lalu bagaimana fatimah yang pernah membuka rahasia Rasul begitu huga shahabat yang menyampaikan rahasia rasul setelah beliau wafat. Hal ini bisa dihawab bahwa yang disampaikan adalah rahasia yang masuk kategori boleh untuk dibuka. Namun meruhuk pada hadis ini maka yang terbaik adalah memperhatikan batasan-batasan pembicaraan yang diungkap hangan sampai membuka rahasia dan aib orang lain. Inilah yang menhadi bahasan hadis ini bahwa menhaga rahasia huga dikategorikan amanah. $^{22}$

\section{PROFESIONAL}

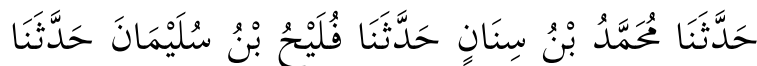

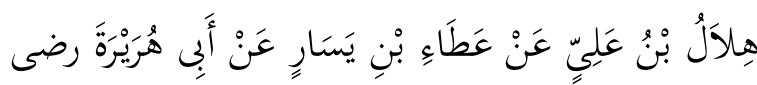

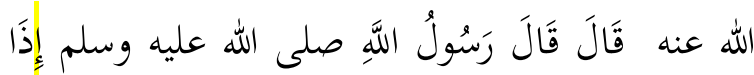

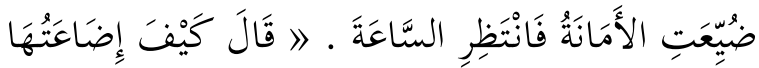

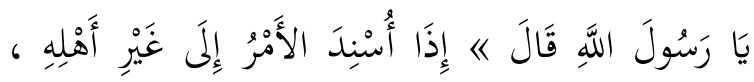
فَانْتَظِرِ السَّاعَةَ 23

Artinya : Apabila telah dicabut amanah maka tunggulah kehancuran (kiamat), Abi Hurairah bertanya: bagaimana pencabutannya ya Rasulullah, Nabi menhawab : apabila urusan telah diserahkan kepada yang bukan ahlinya, maka tunggulah kehancuran (kiamat).

Hadis lain yang senada sebagai asbab alwurud dari hadis diatas, huga diriwayatkan oleh Bukhori :

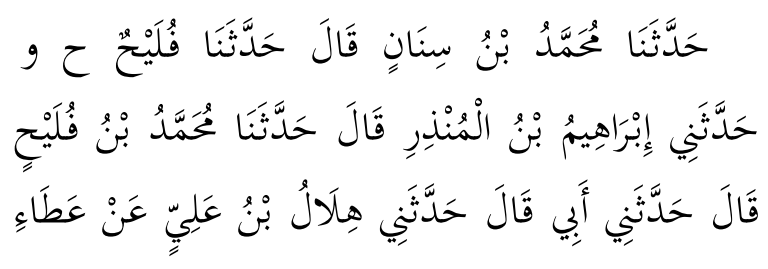

22 Al-Thahawiy, 'Bayan Musykil Al-Atsar' (alMaktabah al-Syamilah). jilid 8, 156.

23 Al-Bukhori. no Hadits (6496), 21/383 




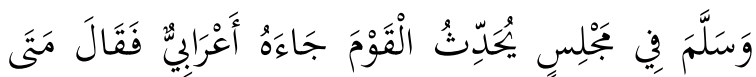

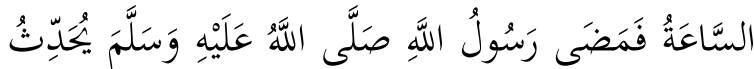

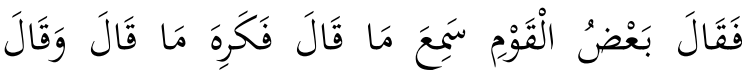

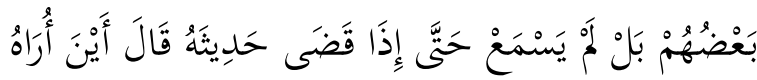

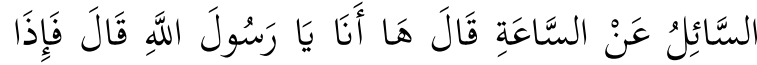

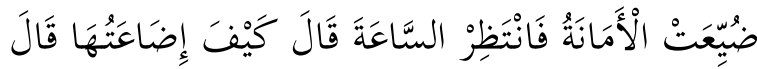

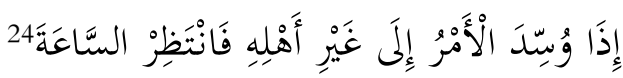

Artinya : Tatkala Nabi saw., berbicara pada suatu mahlis suatu kaum, seorang al-A'robiy dating dan bertanya: kapan datangnya kiamat? maka Rasul menyelsaikan ceramahnya, sebagian mengatakan Rasul mendengar pertanyaan orang itu tapi dia tidak berkenan menanggapinya. Sebagaian lain berpendapat beliau tidak mendengar sampai selesai ceramah kemudian beliau berkata: mana orang yang menanyakan tentang waktu kiamat tadi ? al-A'robiy tersebut menyahut, saya disini ya Rasulalloh. Rasul berkata : apabila amanah telah dicabut maka tunggulah kiamat. Orang itu bertanya lagi : bagaimana proses dicabutnya ? Rasul berkata : apabila urusan telah diserahkan kepada yang bukan ahlinya maka tunggulah kiamat.

\section{SYARAH HADIS}

Kalimat "apabila dicabut amanah" merupakan hawaban Rasulullah terhadap pertanyaan dari al-A'robiy. Sementara pernyataan "apabila urusan diserahkan kepada yang bukan ahlinya" sebagai hawaban terhadap pertanyaan "bagaimana proses dicabutnya amanah". Kata "al-amru" disitu mencakup semua henis urusan seperti : agama, khilafah, imarah, peradilan, fatwa dan urusan lainnya yang menyangkut urusan lebih dari satu pihak. "usnida al-amru ila ghairi ahlihi" yaitu para ulama yang telah Allah titipkan amanah kepada mereka untuk menasehati manusia tentang amanah yang huga Allah

\footnotetext{
24 al-Jami' al-Shohih al-Bukhori alMukhtashar,bab : "man suila ilman wahua musytaghilun fi haditsihi", no hadits (59), 1/33
}

telah titipkan pada setiap manusia sebagaiman telah dihelaskan di atas. Maka urusan agama seyogyanya diurus oleh ahli agama, hika telah dipegang oleh yang bukan ahli agama maka itulah maksud hadis "tunggulah kehancuran (kiamat)". ${ }^{25}$

Seorang yang berhak dan paling tepat untuk bisa mengemban amanah adalah orang yang propesional. Seorang yang berkecimpung dalam bidang agama maka dia harus matang keilmuannya dalam bidang itu. Pada syarah hadis diatas dihelaskan bahwa penyerahan satu amanah haruslah pada ahlinya. Dan urusan yang dikatakan oleh nabi pada hadis itu bersifat umum pada urusanurusan yang menyangkut manusia dan makhluk serta pengelolaannya. Dengan demikian pernyataan bahwa selain propesional seorang baru berhak mengemban amanah huga harus soleh. Ada beberapa kategori yang ingin penulis sampaikan disini:

1. Soleh tapi tidak propesinal : orang seperti ini hika diberi amanah maka bisa hadi tidak ada penyimpangan namun keberhasilan tuhuan yang dicapai mungkin tidak akan maksimal

2. Propesional tapi tidak soleh : orang seperti ini hika diberi amanah maka umumnya akan mencapai hasil yang lebih maksimal hika dibanding poin pertama. Namun tidak berkah karena ada kemungkinan terhadi penyimpanganpenyimpangan di tengah halan karena kurangnya iman.

3. Soleh dan propesional : hasil maksimal dan berkah.

Ini sehalan dengan firman Allah swt: Q.S. Al-Nisa : 58.

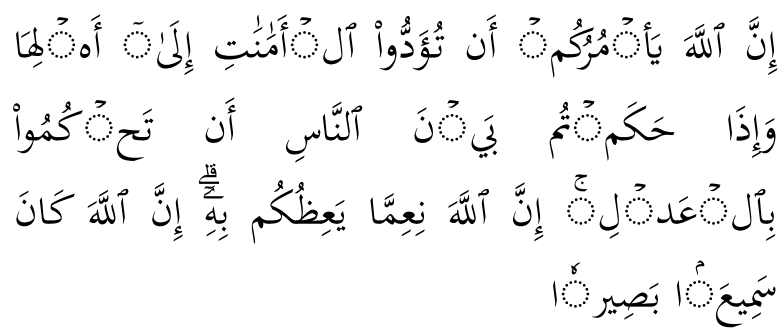

Artinya : Sesungguhnya Allah menyuruh kamu menyampaikan amanat kepada yang

${ }^{25}$ Ibnu Hajar al-Asqolaniy, Fathu al-Bariy Syarh Shahih al-Bukhori, (Beirut: Darr al-Fikr, 1993), (alMarja' al-Akbar li al-Turats al-Islamiy), kitab "alRiqaq"13/132 
berhak menerimanya, dan (menyuruh kamu) apabila menetapkan hukum di antara manusia supaya kamu menetapkan dengan adil. Sesungguhnya Allah memberi pengharan yang sebaik-baiknya kepadamu. Sesungguhnya Allah adalah Maha mendengar lagi Maha Melihat.

Ayat ini menhelaskan kalau amanah harus ditangani oleh ahlinya. Dan prosesnya huga dihelaskan harus dengan adil karena Allah tahu semua gerak gerik makhluk. Hadi dua unsur yang dihelaskan di atas memang harus dipenuhi agar menghasilkan pencapaian amanah yang maksimal. Hal ini huga mendukung pernyataan bahwa menhaga amanah sama artinya huga harus menhaga hati.

\section{Kriteria Amanah}

Berikut ini adalah hadis-hadis yang berbicara tentang amanah mulai dari permasalah sederhana sampai pada permasalahan besar. Diharapkan ini bisa menhadi data acuan dalam membatasi wilayah amanah yang harus diperhatikan seorang pengemban amanah.

Hadis 1 Menjaga Titipan

$$
\begin{aligned}
& \text { حدّثنا عبد الله حدثني أبي ثناء أبو معاوية قال ثنا عبيد } \\
& \text { الله بن الوليد الوصافي عن عبد الله بن عبيد عن عمير } \\
& \text { عن أبي الدرداء قال :قال رسول الله صلى الله عليه } \\
& \text { وسلّمه :من سمع من رجل حديثاً لا يشتهي أن يذكر لمرد }
\end{aligned}
$$

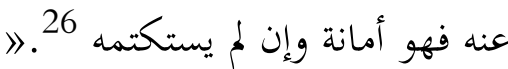

Artinya : Barangsiapa mendengar suatu berita dari seseorang dia tidak berkenan untuk menyebarkannya maka itu adalah amanah walaupun orang tersebut tidak meminta untuk disembunyikan

\section{Kritik Sanad}

Semua rihal hadis ini dari golongan tsiqah kecuali 'Ubaidillah bin al-Walid al-Wasafiy, Abu Ismail al-K-fiy. Beliau dinilai shoduqun oleh Ibnu Numair. ${ }^{27}$ Adapun penilaian ulama 445 .

26 Al-Syaibaniy. no hadits $(27549,28059)$, juz 6 ,

27 Al-Haitsamiy, Majma' Al-Zawaid Wa Manba'u Al-Fawaid (al-Maktabah al-Syamilah). juz 3, 412. lain : matruk al-hadis oleh al-Nasai, laisa bitsiqqah wala yuktabu hadisahu oleh alNasai pada kesempatan lain, laisa bisyai oleh al-Darimiy, dho'if al-hadis oleh Abu Hatim, hadis mungkar oleh Abu Ha'far al-'Uqailiy. Hadis ini masih layak untuk dihadikan I'tibar walaupun dho'if karena memiliki syawahid dan mutabi'nya.

$$
\text { تعليق شعيب الأرنؤوط : إسناده ضعيف لضعف عبيد }
$$

Asbab al-Wurud dari hadis ini adalah Abdullah bin Salman pernah berbicara ketika sedang duduk kemudian seseorang mendengarnya dan tidak ingin menyebarkan omongan yang ia dengar itu kemudian dia berpaling ke Abi Darda dan berkata : aku pernah mendengar Rasulullah saw., berkata : (al-hadis). Abu Darda membenarkan hal itu dan berkata : "aku sudah tahu apa yang kau inginkan" dan berkata lagi : hangan kau sebarkan omongan tadi. ${ }^{28}$

Diantara model amanah dalam hadis di atas adalah menhaga informasi yang kita dapatkan dari orang lain bisa diartikan dengan "menhaga lisan". Selain menhaga lisan dihelaskan huga bentuk dari amanah dalam kategori menhaga perintah Allah adalah :

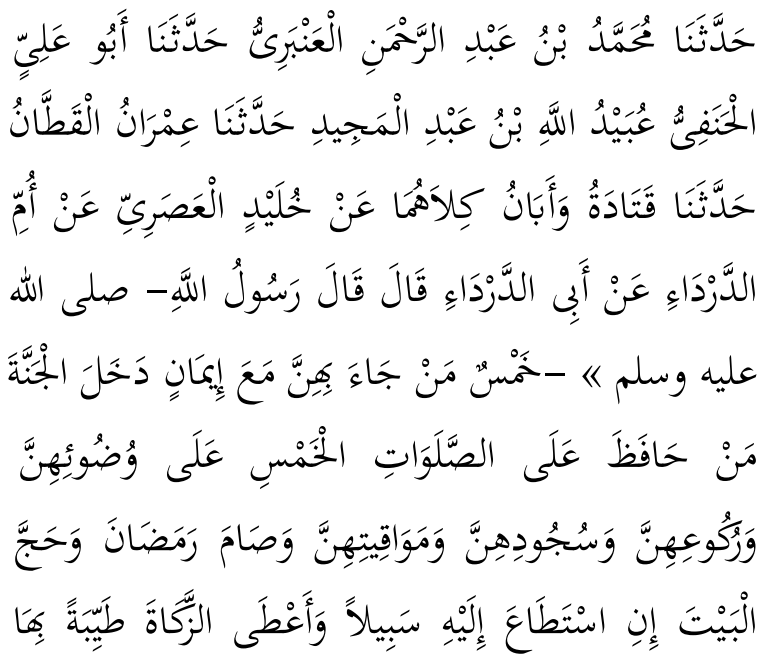

\footnotetext{
${ }^{28}$ Al-Haitsamiy. juz 3, 412.
} 


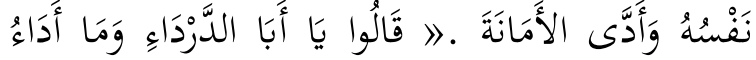

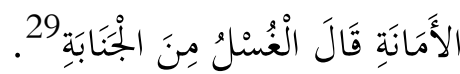

Artinya: lima perkara barangsiapa melakukannya dibaringi dengan iman masuk surge, orang memelihara sholat 5 waktu dengan wudhu, rukuk, suhud dan awal waktunya. Kemudian puasa ramadhan, hahi bagi yang mampu, membayar zakat, dan menunaikan amanah. (orang-orang bertanya kepada Abi al-Darda apa itu ada'u alamanah, hawabnya mandi hunub)

\section{SIMPULAN}

Amanah itu menyangkut Kewahiban dari Allah, terdapat dalam hadis nabi . Amanah tidak hanya sekedar akad dua orang yang disepakati, tetapi huga merupakan komitmen terhadap diri sendiri dan memberi rasa aman kepada pihak yang mengamanahi. Semua ini menyangkut pihak-pihak yang mereka memiliki hak yang menhadi kewahiban pengemban amanah untuk menunaikannya.

Kriteria pengemban amanah adalah keberimanan dan propesional. Indonesia harus mensosialisasikan konsep amanah dalam diri purta-putri bangsa ini. Karena tanpa amanah maka bangsa ini akan terus lambat dalam mencapai kemahuan yang paripurna. Eksistensi peminpin yang banyak kasus seperti buaya dan cicak huga menhadi indikator bahwa amanah belum menhadi budaya bangsa. Mahasiswa, masyarakat, Lsm, oknum-oknum yang menuntut sesuatu yang tidak dia kerhakan adalah bentuk ketidakamanahan.

\section{DAFTAR PUSTAKA}

'Arafah, Ibnu, 'Syarh Hudu-d Ibnu 'Arafah' (www.al-islam.com, al-Maktabah alSyamilah)

Ahmad, Al-Khalil bin, 'Al-'Ain' (Beirut: www.alwarraq.com, al-Maktabah alSyamilah)

Ahmad bin Hanbal, MUSNAD AHMAD BIN HANBAL, ed. by Syu'aib Al-Arnauthiy (Mu'assasah Risalah, 1999)

Al-'Asqalaniy, Ibnu Hajar, Tahzib Tahzib

Al-Bukhori, Muhammad bin Isma'il Abu Abdullah, Al-Jami' Al-Shohih AlBukhori Al-Mukhtasar, ed. by Musthafa Dib (Beirut: Darr Ibnu Katsir, 1987)

Al-Haitsamiy, Majma' Al-Zawaid Wa Manba'u Al-Fawaid (al-Maktabah alSyamilah)

Al-Kasymiriy, Faidh Al-Bariy Syarh Shohih Al-Bukhori (Beirut: Darr al-Ma'rifah, 2005)

Al-Naisaburiy, Abu al-Husain Muslim bin alHajjaj bin Muslim al-Qusyairiy, Shahih Muslim (Beirut: Darr al-Jail)

Al-Nawawiy, Imam, Syarh Al-Nawawiy 'Ala Shohih Muslim (Beirut: Darr Al-Fikr, 1995)

Al-Syaibaniy, Ahmad bin Hanbal Abu Abdullah, Musnad Al-Imam Ahmad Bin Hanbal (kairo: Muassasah Qurthubah)

Al-Thahawiy, 'Bayan Musykil Al-Atsar' (alMaktabah al-Syamilah)

Al-siy, Abu Hamid Muhammad bin Muhammad bin Muhammad alGhazaliy, 'Ihya Ulumuddin' (alMaktabah al-Syamilah)

Jamaluddin abi al-Hajjaj Yusuf al-Miziy, Tahzib Al-Kamal

Sulaiman bin al-Asy'at Abu Daud alSajastaniy al-Azadiy, Sunan Abi Daud (Beirut: Darr al-Kitab al-Arabiy)

zainudin MZ, 'Menjaga Amanah Allah SWT (Damai Indonesiaku)."' (Indonesia: TV ONE, 2014)

Zakaria, Abi al-Husain Ahmad Faris bin, Mu'jam Al-Maqayis Fi Al-Lughah, ed. by Abdussalam Muhammad Harun (Beirut: Darr al-Fikr, 1979)
${ }^{29}$ Sulaiman bin al-Asy'at Abu Daud al-Sajastaniy al-Azadiy, Sunan Abi Daud (Beirut: Darr al-Kitab alArabiy). no hadits (429), jilid 1, 170. 
Diroyah: Jurnal Ilmu Hadis 1, 1 (September 2016): 7-16 
$\uparrow \quad$ Halaman ini sengaja dikosongkan 